\title{
Android Application for Children to Learn Basic Solat
}

\author{
https://doi.org/10.3991/ijim.v13i07.10758 \\ Norhasyimah Hamzah $\left({ }^{凶}\right)$ \\ Universiti Tun Hussein Onn Malaysia (UTHM), Malaysia \\ hasyimah@uthm. edu.my \\ Noor Dayana Abd Halim \\ Universiti Teknologi Malaysia (UTM), Malaysia \\ Mohammad Hafiz Hassan, Arihasnida Ariffin \\ Universiti Tun Hussein Onn Malaysia (UTHM), Malaysia
}

\begin{abstract}
The existence of mobile learning application has provided an opportunity for Islamic knowledge to be delivered widely. Accordingly, Muslim application developers have been developing Islamic-based applications for learning about hadith, prayer (solat), and Quran recitation, to list a few. The solat is the pillar of worship that helps Muslims to become better people. Therefore, it is the responsibility of parents to teach their children about solat, particularly when the latter reach the early age of seven. This study aims to (i) develop and incorporate a prayer-learning application that has multimedia elements in order to attract young users and (ii) assess the reliability of the application for children. A learning application can serve as a new method for learning about how to perform a solat. In this approach, solat can be taught digitally using a portable platform, including Android. In this study, an android learning application was developed using Waterfall methodology which consists of five phases: idea, analysis, design, development, evaluation, and final product. Adobe Flash Professional CS6 was chosen as a development platform. The application consists of four modules: "Let's Pray," "Five Times Prayer," "Doa' After a Prayer," and "Mind Test." To authenticate the application, the researchers collected data from expertise (lecturers) from the Faculty of Technical and Vocational Education and Faculty of Science, Technology, and Human Development. These respondents were selected through targeted sampling. The result concludes that the application is suitable for new learners to learn about performing a solat.
\end{abstract}

Keywords-Android application; Learning Basic Solat, Childhood

\section{Introduction}

In the modern-day sophisticated era, a learning process can take place with a great array of learning-oriented gadgets, including computers and smartphones. The smartphone particularly has become a necessity for every human being because its applications (apps) can complement almost all aspects of human lives. In 2011 alone, 
over 300 million apps were developed for smartphones that run on Android and Iphone operation system (iOS) [1].

According to [2], the development in multimedia technology promises great potential in changing, among others, (i) the way people learn, (ii) the means to obtain information, and (iii) the measures to customize information. The multimedia technology also provides various opportunities for educators to apply various teaching techniques, and learning with the use of multimedia teaching aids can attract children.

The application distribution platform on Google Play categorizes apps into 27 types, among which are religion, education, social, and games. Nevertheless, Islamic religious applications have been poorly develop, despite the increasing demand [3]. The Islamic applications for the practices of Shafi'e sect are even more scarce, necessitating thus an application that can serve as a fundamental guide for students in shafi'ah schools to learn the practice of solat.

\section{$2 \quad$ Prayer Basic Learning}

The five daily prayers are obligatory in Islam. According to Prophet Muhammad S.A.W (narrated by Tarmizi, Abu Daud, Ibn Huzaimah in Mutawalli Sya'rawi, 2007), children need to learn to pray when they are seven years of age, and they can be beaten when they refuse to do so at the age of ten. This hadith upholds that obligatory prayers must be implement by childhood at 7 years old and above.

In the book Mutawalli Sya'rawi (2007), Abu Daud narrates that the Prophet S.A.W said that "the difference between Muslims and non-Muslims is solat, therefore whoever abandons the prayer means infidelity." This narration attests that solat is a crucial obligation. Therefore, in performing a solat, one must fulfill its thirteen pillars (rules), which are (i) the stand for the capable, (ii) intent, (iii) takbiratul of ihram, (iv) reading the Surah Al-Fatihah, (v) bowing, (vi) iktidal, (vii) prostration, (viii) sitting between two prostrations, (ix) sitting the final tahyat, (x) reading the final tahyat, (xi) making salawat to the Prophet, and (xii) greeting first, and (xiii) orderly (Shamsul, 2014). Deserting any of these pillars will annul the prayer.

Many hadiths of Rasulullah emphasize the command to improve a solat in terms of practice and khusyuk (concentration) [4]. Therefore, an android application will be designed to display the playback of every solat in detail using animated graphical display. The application is in line with today's technological developments that make applications accessible at any place and time [5].

\section{The Approach of Behaviourism Learning Theory}

The behaviourism theory proposes that learning is an externally observed behavior. Learning can occur when there is a correlation between stimulus and response. According to [6], repeated stimuli and responses serve as the grounds for learning to take place. The premise of the behaviourism learning theory is to prioritize elements, a mechanism, the role of the environment, reactions or responses, and the importance of the role. Learning outcome is the result of the desired behaviour. According to [7], the 
development of a person's personality or behaviour is due to his or her response to external stimulus.

The use of computer-based teaching methods often involves behaviourism. For example, a mind-test activity found in an android solution learning application with the use of mobile software requires a step-by-step learning process until the learner fully understands the concept. This process also takes place when the user interacts with the computer using a learning-based application.

Besides that, for children to understand or learn how to pray is a self-learning process. Children will focus on sight, sound, and treatment, and thus the behavioural theory (behaviourism). This theory is a thought approach that emphasizes the role of a controlling behaviour. For example, learning is a behaviour that can be observed, controlled, and predicted and learning is a common process because relationships between external stimuli and individual responses can be built to produce consistent behavioural changes.

\section{$4 \quad$ Problem Statement}

The increasing popularity of gadgets, children are becoming more vulnerable to influence and parents are taking the opportunity to educate their children with the use of applications. Through applications, children can learn not only how to read and write but to calculate and learn religious knowledge, such as reading jawi (Arabic handwriting) and performing prayers.

Hence, the learning of solat from books is ineffective for children nowadays because in the current era, children are influence to learn something from android applications. According to [8], one of the ways to improve the effectiveness of communication in teaching is through technology applications. The use of applications or equipment can also improve learning at school level because such method can motivate students and increase their understanding on the practice of solat [3]. The necessary resources include Islamic basic manuals and Islamic-based applications. Prayer lesson using essential andoird apps among children as it is the main holding of the Muslims to apply prayer lesson from 7 years old. This is because, the five times prayer in a day is required by 'His Creator' on every human being to become the noble and responsible person.

\section{$5 \quad$ Research Objectives}

The objectives of this study thus are to:

- Develop a basic android application with multimedia elements for learning how to perform a prayer that can attract childhood;

- Test the functionality of the android application in learning basic solat for childhood by experts and respondents (children). 


\section{$6 \quad$ Research Methodology}

The Waterfall Model founded by Winston Royce as a guideline in this study. The model proposes six phases, namely idea, analysis, design, development, test, and final product [9]. The idea phase is the most important stage because this phase will cover the issues concerning the development of the android application. In this phase, the background of this study and the problem statement are identify. The appropriate goals and means to produce quality products are also established. The analysis phase is crucial for the researcher to understand the weaknesses and advantages of the existing technology systems. These systems have been used as references to facilitate the analysis of the collected information. The purpose of studying the technology systems is to develop an android application that can meet the needs of users. In this phase, the researchers also studied the information of the learning of basic prayers with expert in this learning (expert in islam religion such as ustaz and ustazah at UTHM). In particular, content analysis was performed by comparing existing apps with the developed application in terms of features that need to be improved to meet the needs of target users. Software and hardware requirements were identified and the media elements for the application were also determined.

The design phase of the application was implemented by developing storyboards, creating flow charts, forming navigation structures, designing content structures, and graphing designs. The storyboard was produced by guiding a concept and storyline that corresponds to the target users. Complete storyboarding results were used as preliminary guideline for the project development phase. Predictive solitaire Android apps were designed based on the content structure. The main menu consists of four main modules namely "Let's Prayer," "Five Prayers," "Prayer After Prayer," and "Test of Mind." Each module conveys the importance of useful applications to users. The graphic designs included the character design, the concept selection, and the themes created, which include the menu buttons and backgrounds used for the application. The colors for the application were determined by the features and concept of the animation.

In the development phase, modern technology was used to develop the application. This phase was carried out by installing the application in an Android mobile device. The application was first published using Adobe Flash Professional CS6 and was exported to the appropriate .apk format prior to installation. In the testing phase, the application was tested to the target users. The initial testing phase took place during the development phase. This phase served to identify whether the objectives of the project were achieved in terms of the criterion of meeting the needs of consumers. In this phase, knowledge on how to improve the performance of the application is required. According to [10], listed two types of evaluation: formative evaluation and summative evaluation. In this study, formative assessment was used throughout the development phase and each stage was evaluated during the design.

The application was assessed to ascertain whether the functionality of Andorid Basic Solution Principles have met the project requirements. After the product was used by the consumers, a summative assessment was carried out through user reactions. Results from the evaluation were considered and any shortcoming of the appli- 
cation was corrected in order to conform to user's needs. Users' reactions were assessed through interviews and questionnaire survey. The respondents consisted of ten (10) randomly selected children aged between seven and ten. Learning with the application was assessed by experts in application-based application technology development and religious knowledge. The questionnaire form contains items that seek the experts to evaluate the application in terms of design, interaction, and interface. The responses were analyzed by the frequency of "yes" responses.

The questionnaire contains four sections: Section A, which contains three items (respondents' demographics), Section B, which contains five items (informative design), Section $\mathrm{C}$, which contains five items (interaction design), and Section $\mathrm{D}$, which also contains five items (interface presentation). The final product is then presented to the general users, including the supervisor and the appraisal panel who will rate the score for the application. In this phase, errors or weaknesses of the application were fixed. The product was assessed in terms of its effectiveness for use by the community, particularly children. The Basic Learning Android Application of this prayer was developed to become a reference for people to learn the routine of solat at any time and place. The assessment can indirectly enhance the community's understanding of the importance of prayer.

\section{$7 \quad$ Research Findings}

The experts interviewed consisted of lecturers from Universiti Tun Hussein Onn Malaysia (UTHM), and the target consumers were represented by ten (10) children, aged between six and nine, who were randomly selected from two schools. The data obtained were calculated using percentage of frequency values. The three lecturers were involved in evaluating the functionality of the application. The experts involved were two lecturers from the Faculty of Technical and Vocational Education (FPTV) and a lecturer from the Faculty of Science, Technology, and Human Development (FSTPi). Two experts from FPTV were engaged to evaluate the application's interaction designs, multimedia presentation elements, and user interface. The lecturers from FSTPi were requested to evaluate the content of the application. Interface for android app main menu was shown in Figure 1 which consist of four menu developed (Let's Pray, Five Times Prayer, Doa' After a Prayer, and Mind Test).

Example of the interface for the learning material within the android apps is shown in Figure 2. 


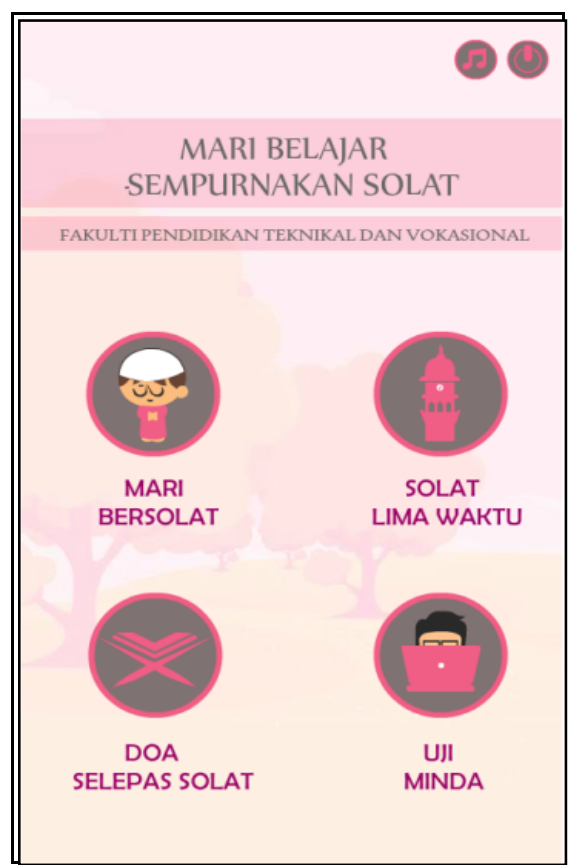

Fig. 1. Main menu of the Android Apps

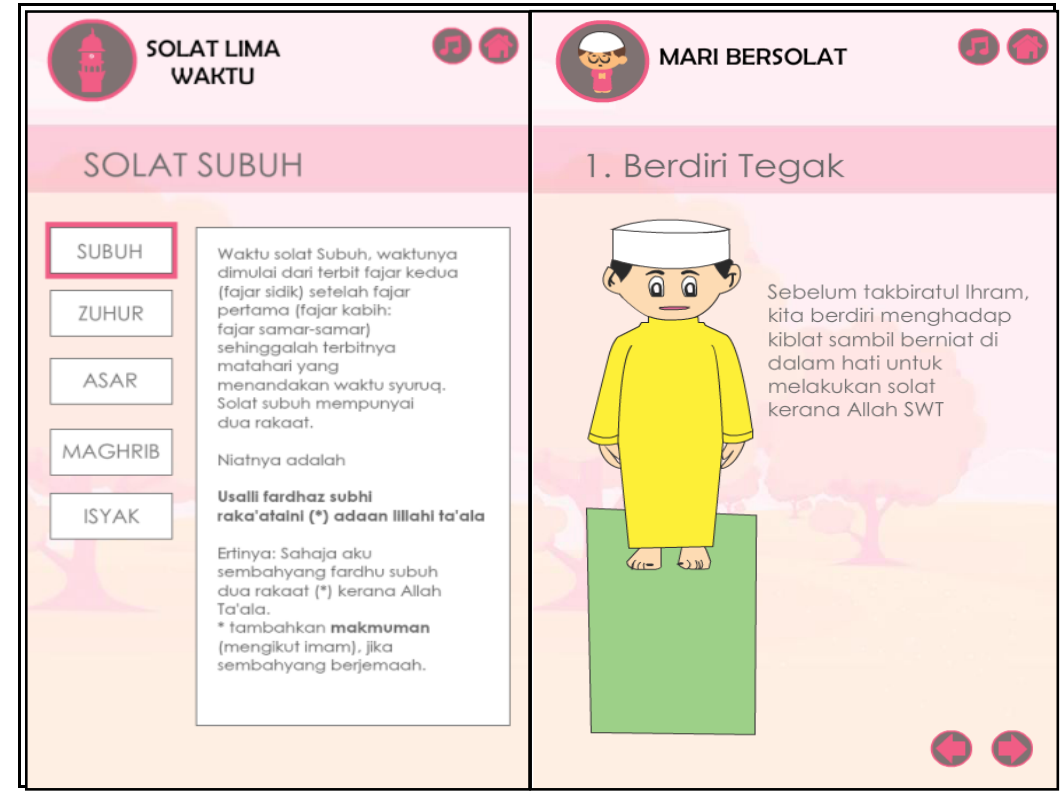

Fig. 2. Interface of the Learning Basic Solat 
Table 1 shows results from the content analysis. The three experts test in functionality of android apps. For item 3, the content of this android application corresponds to different user cognitive levels shows two from three expert no agree with this item. In general, the respondents stated that the content is well organized, and all of them (three experts) agreed that the information is presented accurately. Next, all of experts agreed that the content and texts used are simple and easy to understand.

Table 1. Analysis of Content Design

\begin{tabular}{|c|l|c|c|}
\hline \multirow{2}{*}{ Item } & \multicolumn{1}{|c|}{ Statement } & Frequency \\
\cline { 3 - 4 } & & Yes & No \\
\hline 1 & The content of this android application is clear & 3 & 0 \\
\hline 2 & The content of this android application corresponds to the learning needs & 3 & 0 \\
\hline 3 & The content of this android application corresponds to different user cognitive levels & 2 & 1 \\
\hline 4 & This android application content is well organized & 3 & 0 \\
\hline 5 & The information in this android application provided is accurate & 3 & 0 \\
\hline 6 & The text used describes the contents of the lesson to be submitted & 3 & 0 \\
\hline 7 & The text used in this android application simplified is easy to understand & 3 & 0 \\
\hline 8 & The articles used can be read easily & 3 & 0 \\
\hline
\end{tabular}

Table 2 shows the analysis of multimedia elements of the presentation. Two from three experts mentioned that the graphics used in this android application could attract user's attention. Otherwise, for other items all experts agreed that the presentation design suitable with android apps.

Table 2. Analysis of Presentation Design

\begin{tabular}{|c|l|c|c|}
\hline \multirow{2}{*}{ Item } & \multicolumn{1}{|c|}{ Statement } & Frequency \\
\cline { 3 - 4 } & & Yes & No \\
\hline 1 & The graphics provided can increase user interest & 3 & 0 \\
\hline 2 & The graphics provided can improve user understanding & 3 & 0 \\
\hline 3 & The provider of android application can help increase user interest & 3 & 0 \\
\hline 4 & The provided android application helps to increase user understanding & 3 & 0 \\
\hline 5 & The graphics used in this android application can attract users attention & 2 & 1 \\
\hline 6 & The music background of this android application used is appropriate & 3 & 0 \\
\hline
\end{tabular}

Table 3 shows that the interface display contains four items. Only one item from analysis of interface design show that item 17, two from three experts mentioned that the position of the text in this android application interface is consistent. Otherwise, for other items all experts agreed that the interface design suitable with android apps.

Table 3. Analysis of Interface Design

\begin{tabular}{|c|c|c|c|}
\hline \multirow{2}{*}{ Item } & \multirow{2}{*}{ Question } & \multicolumn{2}{|c|}{ Frequency } \\
\hline & & Yes & No \\
\hline 1 & This android application interface design is appealing & 3 & 0 \\
\hline 2 & The design of this android application interface is appropriate & 3 & 0 \\
\hline 3 & The position of the text in this android application interface is consistent & 2 & 1 \\
\hline 4 & The position of the graphic in this android application interface is consistent & 3 & 0 \\
\hline
\end{tabular}


Table 4 shows that analyse (respondents) children's acceptance of content design. By using structure interview include of 10 respondents (among children). All item from analysis of content design show that all respondents agree that suitable with the content.

Table 4. Analyse respondent's acceptance of content design

\begin{tabular}{|c|l|c|c|}
\hline \multirow{2}{*}{ Item } & \multicolumn{1}{|c|}{ Question } & \multicolumn{2}{c|}{ Frequency } \\
\cline { 3 - 4 } & & Yes & No \\
\hline 1 & Submission of interesting subject matter & 10 & 0 \\
\hline 2 & Organized and interesting content & 10 & 0 \\
\hline 3 & The content of the lesson is in line with my level of understanding & 10 & 1 \\
\hline 4 & I can understand the contents of the lesson clearly & 10 & 0 \\
\hline
\end{tabular}

Table 5 shows that analysis of respondents' acceptance of interaction design. By using structure interview include of 10 respondents (among children). All item from analysis of interaction design show that all respondents agree that suitable.

Table 5. Analysis of respondents' acceptance of interaction design

\begin{tabular}{|c|l|c|c|}
\hline \multirow{2}{*}{ Item } & \multicolumn{1}{|c|}{ Question } & \multicolumn{2}{c|}{ Frequency } \\
\cline { 3 - 4 } & & Yes & No \\
\hline 1 & The graphics provided can increase user interest & 10 & 0 \\
\hline 2 & Audio can be heard clearly & 10 & 0 \\
\hline 3 & Interestingly used music & 10 & 0 \\
\hline 4 & The control button works fine & 10 & 0 \\
\hline 5 & The resulting animation is age-appropriate & 10 & 0 \\
\hline
\end{tabular}

Table 6 shows Analysis of respondents' acceptance of interface design. By using structure interview include of 10 respondents (among children). All item from analysis of interface design show that all respondents agree that suitable.

Table 6. Analysis of respondents' acceptance of interface design

\begin{tabular}{|c|l|c|c|}
\hline \multirow{2}{*}{ Item } & \multicolumn{1}{|c|}{ Question } & \multicolumn{2}{c|}{ Frequency } \\
\cline { 3 - 4 } & & Yes & No \\
\hline 1 & Interesting interface display & 10 & 0 \\
\hline 2 & Background color is appropriate & 10 & 0 \\
\hline 3 & The layout shown on the screen is appropriate & 10 & 0 \\
\hline 4 & The graphics used are appropriate & 10 & 0 \\
\hline 5 & The colors used are appropriate & 10 & 0 \\
\hline
\end{tabular}

\section{Discussions}

The Waterfall Model was used to guide the development of the android application which contains lessons of basic prayers for childhood. The development involved six phases namely idea, analysis, design, development, testing, and final product. In the design stage, Adobe Flash CS6 and Sound Forge were used to develop a basic An- 
droid application for teaching children the basic routine of solat. The application was designed with graphics, audio, and text. All the teaching materials are developed in the design phase using appropriate hardware and software [11]. The application was then published in an apk format and hence can be utilized using the the Android Manager app.

Results from this study showed that the layout and design of the application had attracted the respondents' (children) interest. Majority of them agreed that the design and background of the application are appropriate for target users. Therefore, with this android app learning basic prayers in the children, parents do not have to worry about letting kids have smartphones with interesting and useful learning content anytime. As mentioned by Othman [12], the availability of mobile applications has made it easy for users to access the contents at any time and place.

According to [13], residents in an interior without schools, teachers, and students use wireless technology to facilitate the access of information. Technology plays an important role in delivering all instructions and information as well as in facilitating the learning process. In the application developed in this study, the materials are delivered in graphics, texts, animations, and audio. As pointed by [14], a facility for learning offers better technology approaches to education. The use of visual graphic media refers to the images used to make information more interesting and easy to understand. Visual graphs are able to describe concepts that are difficult to be explained by texts. Graphics like drawings, pictures, and charts can also convey information more effectively.

The content of each module is presented in a form of text that facilitates the user to receive the intended message. As pointed by [15], text is one of the major media needed in a multimedia software that intends to deliver its content clearly. Text is the most effective way of bringing ideas to users. In the case of the application developed in the study, the text was intended to deliver comprehensible information to students. In Android apps, an animated media presentation interface in the sequence of two-dimensional static images is used to create motion illusion. The use of animation is also an ideal strategy to attract and engage children. As pointed [16], animation is a form of technology-based learning that can provide a comprehensive learning experience to children.

Another form of media used in the application is audio. Audio is one of the most frequently used media in the interaction between computers and humans. In regard to the application developed for this study, the element of music plays a role in creating a more prominent and exciting interface. As pointed by [17], audio in a multimedia presentation plays a crucial role in bringing an atmosphere to the appropriate learning method.

\section{Conclusion}

In conclusion, the development of an Android-based learning application for teaching solat to children can provide a new learning experience with the use of interactive multimedia elements. The application thus can serve as a tool for teachers and parents 
to teach children about solat from any place and at any time. The researcher therefore hopes that the study can fulfil the needs of children in learning the basics of performing solat and reciting its doa's.

\section{Acknowledgement}

This research was supported by Short Term Grant (STG) at Universiti Tun Hussein Onn Malaysia (U647).

\section{References}

[1] Muhammad Nizam, S.S. (2016). Aplikasi Mudah Alih Pengimbas Kod E Menggunakan Teknologi Pengecaman Aksara. FTSM, 2-11.

[2] Jamalludin Harun, \& Zaidatun Tasir (2003). Multimedia dalam Pendidikan. Kuala Lumpur: Venton Publishing.

[3] Karim, A. \& Lubis, M.A. (2015). Aplikasi Mudah Alih Panduan Solat dan Penggunaannya. Ulum Islamiyyah Journal, 43-61. https://doi.org/10.12816/0028491

[4] Hassan, H. (2008). Personaliti ustaz Dzul dakwah guna multimedia. Kuala Lumpur: Utusan Publications.

[5] Abdul Rahman, K., Kasbun, R., \& Mohd Suhaini, M.N. (2015). Perkembangan Aplikasi Mudah Alih dalam Peyebaran Dakwah Islam. International Conference Of Information Technology \& Society (pp. 230-231). Kuala Lumpur, Malaysia: Kolej Universiti Islam Antarabangsa Selangor.

[6] Yahya, A. \& Bahari, M.S. (2008). Teori-Teori Tingkah Laku Berisiko. Skudai: Universiti Teknologi Malaysia.

[7] Ahmad Johari Sihes (2009). Teori Pembelajaran. Skudai: Universiti Teknologi Malaysia.

[8] Arsat, M. \& Khalip, H. (2005). Penggunaan Perisian Multimedia dalam Pengajaran Guruguru Teknikal. Multimedia Pembelajaran, 23-28.

[9] Royce, M. (1970). Managing The Development Of Large Software System. Proceedings of IEEE WESCON, 1-9.

[10] Mohd Nordin, N. \& Hong, N.C. (2009). Pembangunan dan Penilaian Bahan Pengajaran dan Pembelajaran Berasaskan Web. Jurnal Pendidikan Malaysia, 34 (1), 111 - 129.

[11] Gardner, J. (2012). A basic overview of the Design phase of the ADDIE instructional design model. United State: Vanity Publisher.

[12] Othman, M.I.A. (2016). Aplikasi Mudah Alih Teknik Gerakan Sentuhan Untuk Kanakkanak Pra Sekolah. Bangi: Universiti Kebangsaaan Malaysia.

[13] Ally, M. (2009). Mobile learning transforming the delivery of education and training. Kuala Lumpur: PTS Publications.

[14] Jamaludin, R. (2007). Internet dalam Pendidikan. Pulau Pinang: Penerbit Universiti Sains Malaysia. https://doi.org/10.21315/mjms2016.23.5.1

[15] Hofstetter \& Fred, T. (2001). Multimedia Literacy Third Edition. New York: McGraw-Hill International Edition.

[16] Jamaludin, R. (2005). Multimedia Dalam Pendidikan. Kuala Lumpur: Utusan Publications.

[17] Jamalludin Harun \& Zaidatun Tasir (2000). Pengenalan kepada multimedia. Kuala Lumpur: Venton Publishing. 


\section{Authors}

Dr. Norhasyimah Hamzah is a lecterur in Creative Multimedia Program at Faculty of Technical and Vocational Education, Universiti Tun Hussein Onn Malaysia, 86400 Parit Raja, Batu Pahat, Johor, Malaysia.

Dr. Noor Dayana Abd Halim is a senior lecterur in Department of Science and Mathematics Education and Creative Multimedia, Faculty of Social Sciences and Humanities, Universiti Teknologi Malaysia, 81310 Skudai, Johor, Malaysia.

Dr. Arihasnida Ariffin is a lecterur in Educational Technology at Faculty of Technical and Vocational Education, Universiti Tun Hussein Onn Malaysia, 86400 Parit Raja, Batu Pahat, Johor, Malaysia.

Mohammad Hafiz Hassan is a student in Creative Multimedia program at Faculty of Technical and Vocational Education, Universiti Tun Hussein Onn Malaysia, 86400 Parit Raja, Batu Pahat, Johor, Malaysia.

Article submitted 2019-03-13. Resubmitted 2019-05-29. Final acceptance 2019-06-03. Final version published as submitted by the authors. 